\title{
Association between $N$-methyl-D-aspartate Receptor Subunit 2B Gene Polymorphisms and Personality Traits in a Young Japanese Population
}

\author{
S Narita, Y Onozawa, E Yoshihara, D Nishizawa, M Numajiri, K Ikeda, K Iwahashi
}

\begin{abstract}
Objective: The $N$-methyl-D-aspartate receptor subunit 2B (GluN2B) is involved in regulation of anxiety and depression and nervous activity in the brain. Single nucleotide polymorphisms of the GluN2B gene $(G R I N 2 B)$ are associated with human mental function and behaviour. We investigated whether four GRIN2B polymorphisms (rs7301328, rs1806201, rs1805247, and rs1805502) affect characterisation of personality traits.

Methods: In 248 young people, GRIN2B polymorphisms were analysed, and personality traits were assessed using the Neuroticism Extraversion Openness-Five Factor Inventory (NEO-FFI) and State-Trait Anxiety Inventory (STAI).

Results: There was no main effect of the GRIN2B polymorphisms on the NEO-FFI and STAI dimension scores. Interaction between polymorphism and sex was found in rs $1805247(\mathrm{p}=0.034)$ and rs $1805502(\mathrm{p}$ $=0.040$ ) in terms of the conscientiousness score of the NEO-FFI. However, post hoc simple main effect analysis showed no significant effect. The preliminary haplotype analysis indicated that haplotype CTT (rs1806201-rs1805247-rs1805502) in the haplotype block was associated with the extraversion score of the NEO-FFI in female participants $(\mathrm{p}=0.044)$, but the significance was lost on correction for multiple testing.

Conclusion: There was no significant association between selected GRIN2B polymorphisms and personality traits, but this may be due to low statistical power. Further studies involving a larger study population are needed to clarify this.
\end{abstract}

Key words: Haplotypes; NR2B NMDA receptor; Personality; Polymorphism, genetic

Dr Shin Narita, MS, Laboratory of Physiology (Project of Neurophysiology), Course of Environmental Health Science, Graduate School of Environmental Health, Azabu University, Kanagawa, Japan.

Dr Yuuya Onozawa, PhD, Laboratory of Physiology (Project of Neurophysiology), Course of Environmental Health Science, Graduate School of Environmental Health, Azabu University, Kanagawa, Japan.

Dr Eiji Yoshihara, PhD, Laboratory of Physiology (Project of Neurophysiology), Course of Environmental Health Science, Graduate School of Environmental Health, Azabu University, Kanagawa, Japan.

Dr Daisuke Nishizawa, PhD, Addictive Substance Project, Tokyo Metropolitan Institute of Medical Science, Tokyo, Japan.

Dr Maki Numajiri, MS, Laboratory of Physiology (Project of Neurophysiology), Course of Environmental Health Science, Graduate School of Environmental Health, Azabu University, Kanagawa, Japan.

Dr Kazutaka Ikeda, PhD, Addictive Substance Project, Tokyo Metropolitan Institute of Medical Science, Tokyo, Japan.

Dr Kazuhiko Iwahashi, MD, PhD, Laboratory of Physiology (Project of Neurophysiology), Course of Environmental Health Science, Graduate School of Environmental Health, Azabu University, Kanagawa, Japan \& Addictive Substance Project, Tokyo Metropolitan Institute of Medical Science, Tokyo, Japan \& Health Administration Center, Azabu University, Kanagawa, Japan.

Address for correspondence: Dr Yuuya Onozawa, Laboratory of Physiology (Project of Neurophysiology), Course of Environmental Health Science, Graduate School of Environmental Health, Azabu University, 1-17-71 Fuchinobe, Chuo-ku, Sagamihara, Kanagawa 252-5201, Japan .

Tel/Fax: +81-42-769-1930; Email: onzwy@kitasato-u.ac.jp

Submitted: 23 July 2017; Accepted: 13 December 2017

\section{Introduction}

Personality traits are influenced by environmental and genetic factors. Up to $60 \%$ of the variance in personality traits might be inherited. ${ }^{1}$ Genetic factors have a significant effect on personality traits as measured by the Cloninger model and five-factor model. ${ }^{2}$ Some genes involved in the characterisation of personality traits may affect various human behaviours, including mood disorders and schizophrenia. ${ }^{2}$ Genetic polymorphisms of neurotransmission-related genes are hypothesised to contribute to the formation of personality traits. ${ }^{3}$

$N$-methyl-D-aspartate (NMDA) receptors are glutamate-gated ion channels that are widely expressed in the central nervous system. They play central roles in synapse development and plasticity, and learning and memory. ${ }^{4,5}$ The glutamate-binding site has been localised to the NMDA receptor subunit 2, which is the main molecular determinant of NMDA receptor functional diversity in the brain. ${ }^{6,7}$ The activity of NMDA receptor subunit 2B (GluN2B) contributes to vulnerability to neural excitotoxicity and psychiatric disorders, as well as working 
memory function in the prefrontal cortex. ${ }^{8}$ GluN2B is involved in mental function and behaviour; rats that are more anxious have altered patterns of GluN2B expression in the prefrontal cortex, amygdala, and hippocampus, all of which control emotional behaviour. ${ }^{9}$ In the prefrontal cortex of patients with major depressive disorder, expression of GluN2B is significantly reduced compared with controls. ${ }^{10}$ GluN2B antagonists are efficacious in the treatment of depressive states. ${ }^{11,12}$

The GluN2B gene (GRIN2B) is located on chromosome $12 \mathrm{p} 12$ and consists of 13 exons, the coding sequence being encompassed by exons 2 to $13 .{ }^{13,14}$ Molecular genetic studies have identified GRIN2B as a candidate gene for bipolar disorder. ${ }^{15,16} \mathrm{In}$ a sample of bipolar patients, the $\mathrm{C}$ allele of the rs 1805502 polymorphism in GRIN2B was transmitted more frequently. ${ }^{17}$ Subsequent case-control analysis of GRIN2B polymorphisms and bipolar disorder revealed that the rs 1805247 polymorphism and the haplotype composed of rs 1805247 and rs 1805502 were significantly associated with bipolar disorder in a Chinese Han population. ${ }^{18}$ Patients with and without treatment-resistant depression differ significantly in the allele and genotype frequencies of the rs 1805502 polymorphism. ${ }^{19}$ The rs 1806201 polymorphism has been shown to affect Cloninger type 2 alcoholdependent patients..$^{20}$ In a study of GRIN2B mutations on decision-making using the Iowa Gambling Task, healthy German women with the C/C genotype of the rs1806201 polymorphism made less use of a win-stay strategy and demonstrated more exploratory behaviour during task execution..$^{21}$ The rs 7301328 polymorphism has been linked to schizophrenia in Japanese patients ${ }^{14}$ and disruptive behaviour in Taiwanese volunteers. $^{22}$

GRIN2B polymorphisms may affect the characterisation of personality traits. This study aimed to investigate whether GRIN2B polymorphisms are associated with personality traits in a young Japanese population. We focused on 4 single nucleotide polymorphisms (SNPs): rs $7301328(366 \mathrm{C} / \mathrm{G}$, exon 2), rs 1806201 (2664C/T, exon 13), rs1805247 (4197T/C, exon 13), and rs1805502 (5988T/C, exon 13).

\section{Methods}

This study was approved by the ethics committee of Azabu University, Japan. Written informed consent was obtained from each participant. A total of 248 participants (63 males and 185 females) with a mean \pm standard deviation age of $19.55 \pm 1.21$ years were recruited. Their blood samples were obtained. The personality traits of the participants were evaluated using the Japanese version of the Neuroticism Extraversion Openness-Five Factor Inventory (NEO-FFI) and the State-Trait Anxiety Inventory (STAI). The NEO-FFI is a 60-item self-report questionnaire based on the five-factor model of personality. It assesses the relationship between gene polymorphisms and 5 major dimensions of personality traits (neuroticism, extraversion, openness, agreeableness, and conscientiousness) and provides a comprehensive evaluation of personality traits. ${ }^{23}$ The STAI is a 40 -item self-report questionnaire used to measure 2 major scales of anxiety (state anxiety and trait anxiety). ${ }^{24}$ State anxiety is the strength of anxiety at the moment, and trait anxiety is the tendency to anxiety as a personality trait. Both the NEO-FFI and the STAI are concise and thus facilitate accurate evaluation..$^{23,25}$ Their validity and reliability have been confirmed in a Japanese population..$^{24,26}$

Extraction and purification of genomic DNA was performed using the phenol/chloroform method. GRIN2B polymorphisms rs7301328, rs1806201, rs1805247, and rs 1805502 were genotyped by means of polymerase chain reaction-restriction fragment length polymorphism (PCRRFLP)..$^{14,27}$ The PCR cycling conditions were $95^{\circ} \mathrm{C}$ for 10 min, 35 cycles of $95^{\circ} \mathrm{C}$ for $30 \mathrm{~s}, 56^{\circ} \mathrm{C}(\mathrm{rs} 1806201)$ or $60^{\circ} \mathrm{C}$ (rs7301328, rs 1805247 , and rs 1805502 ) for $30 \mathrm{~s}$, and $72^{\circ} \mathrm{C}$ for $30 \mathrm{~s}$, and final extension at $72^{\circ} \mathrm{C}$ for $7 \mathrm{~min}$. The PCR product (112bp for rs $7301328,210 \mathrm{bp}$ for rs $1806201,320 \mathrm{bp}$ for rs 1805247, and 353bp for rs1805502) was digested with a restriction enzyme, TaqI, PstI, NcoI, or AciI, and the digested products were subjected to electrophoresis, and visualised using the ethidium bromide staining method (Figure 1).

The Hardy-Weinberg disequilibrium was assessed using the $\chi^{2}$ test. We compared the NEO-FFI and STAI dimension scores among the GRIN2B genotypes using two-way analysis of variance, with genotypes and sex as independent variables and NEO-FFI or STAI dimension scores as dependent variables. As a preliminary analysis, we analysed the effects of the haplotypes consisting of the GRIN2B polymorphisms on the NEO-FFI and STAI dimension scores. Linkage disequilibrium (LD) coefficients $\left(D^{\prime}\right.$ and $\left.r^{2}\right)$ and haplotype effects were calculated with gPLINK 2.050 (http://zzz.bwh.harvard.edu/plink/index. shtml) and Haploview 4.2 (http://www.broad.mit.edu/ $\mathrm{mpg}$ /haploview/index.php). ${ }^{28,29} \mathrm{~A} \mathrm{p}$ value of $<0.05$ was considered statistically significant.

\section{Results}

In the 248 participants, the genotype frequencies of the analysed GRIN2B polymorphisms were as follows: rs7301328 (C/C type: $28.2 \%, \mathrm{C} / \mathrm{G}$ type: $51.2 \%, \mathrm{G} / \mathrm{G}$ type: 20.6\%), rs1806201 (C/C type: $31.5 \%, \mathrm{C} / \mathrm{T}$ type: $45.2 \%$, T/T type: $23.3 \%$ ), rs1805247 (T/T type: $55.7 \%, \mathrm{~T} / \mathrm{C}$ type: $38.3 \%, \mathrm{C} / \mathrm{C}$ type: $6.0 \%$ ), and $\mathrm{rs} 1805502$ (T/T type: $56.1 \%$, T/C type: $37.9 \%, \mathrm{C} / \mathrm{C}$ type: $6.0 \%)$. The genotype distribution of the four GRIN2B polymorphisms was in Hardy-Weinberg equilibrium (rs7301328: $\chi^{2}(1)=0.227, \mathrm{p}$ $=0.634 ;$ rs 1806201: $\chi^{2}(1)=2.047, \mathrm{p}=0.152 ; \mathrm{rs} 1805247$ : $\chi^{2}(1)=0.064, p=0.800 ;$ rs1805502: $\chi^{2}(1)=0.029, p=$ $0.866)$. There was no significant difference in the frequency of the GRIN2B genotype between sexes (rs7301328: $\chi^{2}(2)$ $=3.245, \mathrm{p}=0.197 ; \mathrm{rs} 1806201: \chi^{2}(2)=1.969, \mathrm{p}=0.374$; rs1805247: $\chi^{2}(2)=5.590, \mathrm{p}=0.061 ;$ rs $1805502: \chi^{2}(2)=$ $5.689, \mathrm{p}=0.058)$.

The NEO-FFI and STAI dimension scores in the 

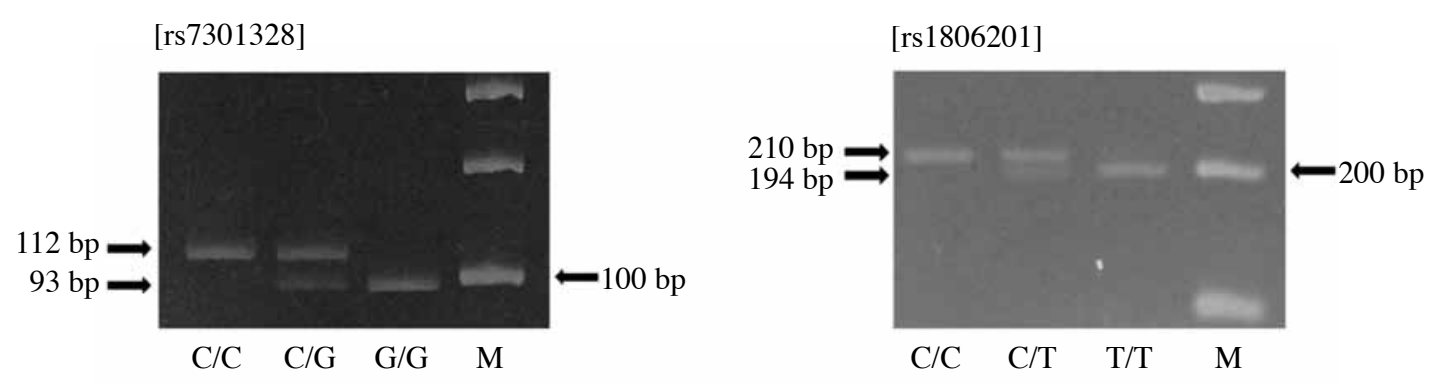

$[\mathrm{rs} 1805247]$

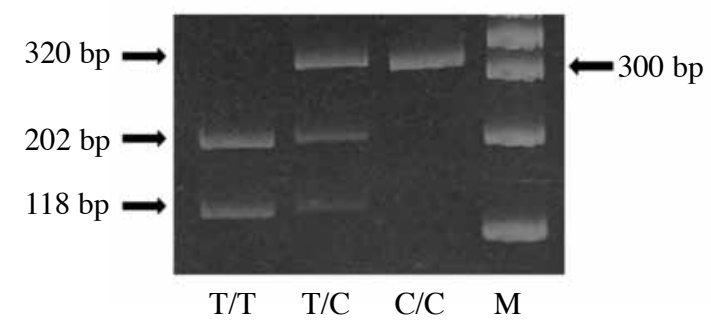

[rs 1805502]

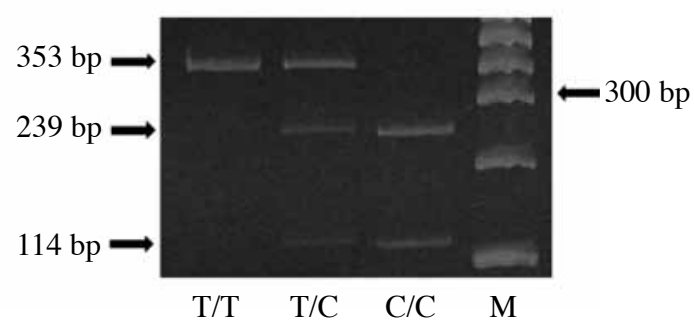

Figure 1. Representative results for the GRIN2B polymorphisms with the PCR-RFLP method.

Abbreviations: GRIN2B $=N$-methyl-D-aspartate receptor subunit $2 B$ gene; $M=100$ bp DNA ladder; PCR-RFLP = polymerase chain reaction-restriction fragment length polymorphism.

participants grouped as GRIN2B genotype are shown in Table 1 . In the two-way analysis of variance, there was no main effect of the GRIN2B polymorphisms on the NEO-FFI and STAI dimension scores. Interaction between the rs7301328 or rs1806201 polymorphisms and sex was not found for any NEO-FFI and STAI dimension scores. In contrast, interaction between the rs 1805247 or rs 1805502 polymorphisms and sex was found for the conscientiousness score of the NEO-FFI (rs1805247: $\mathrm{F}=3.426$, $\mathrm{p}=0.034$; rs1805502: $\mathrm{F}=3.259, \mathrm{p}=0.040)$. However, there was no simple main effect of the rs1805247 or rs 1805502 polymorphisms in either sex on the conscientiousness score (rs1805247: male: $\mathrm{F}=2.268, \mathrm{p}=0.106$, female: $\mathrm{F}=$ 1.429, $\mathrm{p}=0.242$; rs1805502: male: $\mathrm{F}=2.263, \mathrm{p}=0.106$, female: $F=1.200, p=0.303$ ). For other dimension scores, no interaction was observed between the rs 1805247 or rs1805502 polymorphisms and sex.

The LD pattern for the four GRIN2B polymorphisms is shown in Figure 2. Haploview indicated that the rs 1805247 and rs 1805502 polymorphisms showed nearly complete LD $\left(D^{\prime}=1.000, r^{2}=0.989\right)$, and haplotype block 1 composed of the rs1806201, rs1805247, and rs1805502 polymorphisms was detected. Therefore, we performed haplotype analysis for block 1 consisting of 3 markers.

The effects of the GRIN2B haplotypes on participants' NEO-FFI and STAI dimension scores are shown in Table 2. A haplotype CTT (rs1806201-rs1805247-rs1805502) was significantly associated with the extraversion score of the
NEO-FFI in female participants $\left(\mathrm{R}^{2}=0.022, \mathrm{p}=0.044\right)$. However, after correction for multiple testing ( $\mathrm{p}<0.05 /$ 3 [haplotype number] $=0.0167$ ), the significance was lost. There was no significant effect of the haplotype consisting of the three GRIN $2 B$ polymorphisms on the NEO-FFI and STAI dimension scores in either the male participants or total participants.

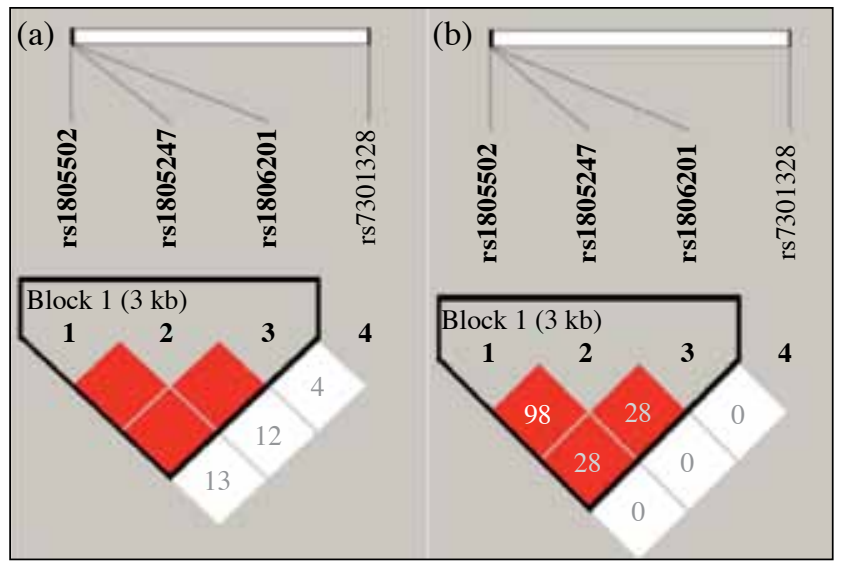

Figure 2. Linkage disequilibrium map of 4 polymorphisms at the GRIN2B locus. Pairwise linkage disequilibrium between SNPs was measured using the (a) D' and (b) $\mathbf{r}^{2}$ values.

Abbreviations: GRIN2B $=N$-methyl-D-aspartate receptor subunit $2 B$ gene; $S N P=$ single nucleotide polymorphism. 
Table 1. NEO-FFI and STAI dimension scores in participants grouped as GRIN2B genotypes.

\begin{tabular}{|c|c|c|c|c|c|c|}
\hline \multirow[t]{2}{*}{ SNP } & \multicolumn{5}{|c|}{ Mean \pm SD NEO-FFI score } & \multirow{2}{*}{$\begin{array}{c}\text { Mean } \pm \text { SD } \\
\text { STAI score } \\
\text { Trait anxiety }\end{array}$} \\
\hline & Neuroticism & Extraversion & Openness & $\begin{array}{l}\text { Agreeable- } \\
\text { ness }\end{array}$ & $\begin{array}{l}\text { Conscien- } \\
\text { tiousness }\end{array}$ & \\
\hline \multicolumn{7}{|l|}{ rs7301328 } \\
\hline \multicolumn{7}{|l|}{ Genotype (male) } \\
\hline $\mathrm{C} / \mathrm{C}$ & $27.29 \pm 6.52$ & $23.57 \pm 8.60$ & $26.43 \pm 7.60$ & $27.43 \pm 7.42$ & $25.29 \pm 8.32$ & $53.73 \pm 9.43$ \\
\hline $\mathrm{C} / \mathrm{G}$ & $30.27 \pm 7.90$ & $23.43 \pm 6.51$ & $25.78 \pm 5.14$ & $28.38 \pm 5.46$ & $25.73 \pm 6.42$ & $50.74 \pm 10.03$ \\
\hline $\mathrm{G} / \mathrm{G}$ & $28.11 \pm 9.10$ & $27.78 \pm 5.67$ & $24.78 \pm 9.09$ & $30.67 \pm 6.42$ & $27.33 \pm 7.07$ & $51.00 \pm 9.09$ \\
\hline \multicolumn{7}{|c|}{ - } \\
\hline $\mathrm{C} / \mathrm{C}$ & $31.82 \pm 7.27$ & $26.07 \pm 7.28$ & $27.87 \pm 6.69$ & $29.44 \pm 5.55$ & $25.82 \pm 6.34$ & $51.89 \pm 9.51$ \\
\hline $\mathrm{C} / \mathrm{G}$ & $30.60 \pm 7.43$ & $24.90 \pm 6.45$ & $28.79 \pm 5.08$ & $29.75 \pm 5.87$ & $25.70 \pm 6.35$ & $50.95 \pm 10.87$ \\
\hline $\mathrm{G} / \mathrm{G}$ & $31.45 \pm 9.60$ & $24.14 \pm 6.60$ & $28.57 \pm 5.58$ & $27.88 \pm 5.84$ & $24.76 \pm 6.50$ & $50.67 \pm 10.72$ \\
\hline Main effect of the genotype & 0.799 & 0.437 & 0.883 & 0.788 & 0.949 & 0.530 \\
\hline $\begin{array}{l}\text { Interaction between the } \\
\text { genotype and sex }\end{array}$ & 0.286 & 0.130 & 0.661 & 0.176 & 0.571 & 0.849 \\
\hline \multicolumn{7}{|l|}{ rs1806201 } \\
\hline \multicolumn{7}{|l|}{ Genotype (male) } \\
\hline $\mathrm{C} / \mathrm{C}$ & $29.90 \pm 7.18$ & $24.43 \pm 8.56$ & $25.67 \pm 5.48$ & $28.86 \pm 6.06$ & $26.62 \pm 8.45$ & $52.36 \pm 9.13$ \\
\hline $\mathrm{C} / \mathrm{T}$ & $28.61 \pm 8.39$ & $23.79 \pm 6.34$ & $26.21 \pm 7.42$ & $28.00 \pm 6.22$ & $25.57 \pm 6.26$ & $50.07 \pm 10.22$ \\
\hline $\mathrm{T} / \mathrm{T}$ & $29.64 \pm 7.84$ & $24.36 \pm 5.73$ & $24.91 \pm 5.28$ & $29.09 \pm 6.20$ & $25.18 \pm 5.47$ & $53.55 \pm 9.75$ \\
\hline \multicolumn{7}{|c|}{ 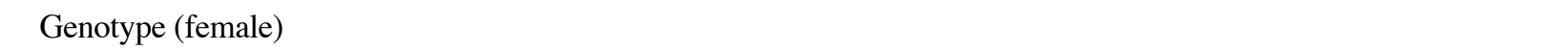 } \\
\hline $\mathrm{C} / \mathrm{C}$ & $31.04 \pm 6.83$ & $23.96 \pm 6.83$ & $28.02 \pm 5.52$ & $29.25 \pm 5.57$ & $26.05 \pm 6.00$ & $51.73 \pm 9.94$ \\
\hline $\mathrm{C} / \mathrm{T}$ & $30.94 \pm 8.58$ & $25.10 \pm 6.71$ & $28.85 \pm 6.18$ & $29.21 \pm 5.93$ & $25.73 \pm 6.32$ & $51.13 \pm 10.93$ \\
\hline $\mathrm{T} / \mathrm{T}$ & $31.68 \pm 7.97$ & $26.34 \pm 6.60$ & $28.32 \pm 5.06$ & $29.23 \pm 5.90$ & $24.53 \pm 6.85$ & $50.57 \pm 10.19$ \\
\hline Main effect of the genotype & 0.806 & 0.713 & 0.668 & 0.853 & 0.556 & 0.635 \\
\hline $\begin{array}{l}\text { Interaction between the } \\
\text { genotype and sex }\end{array}$ & 0.902 & 0.636 & 0.912 & 0.873 & 0.927 & 0.609 \\
\hline \multicolumn{7}{|l|}{ rs1805247 } \\
\hline \multicolumn{7}{|l|}{ Genotype (male) } \\
\hline $\mathrm{T} / \mathrm{T}$ & $28.90 \pm 7.97$ & $24.52 \pm 6.59$ & $26.17 \pm 5.92$ & $28.72 \pm 6.93$ & $26.83 \pm 6.64$ & $52.27 \pm 9.41$ \\
\hline $\mathrm{T} / \mathrm{C}$ & $29.96 \pm 7.91$ & $23.42 \pm 7.04$ & $24.63 \pm 7.20$ & $28.08 \pm 5.65$ & $23.83 \pm 7.39$ & $50.52 \pm 10.24$ \\
\hline $\mathrm{C} / \mathrm{C}$ & $28.29 \pm 7.41$ & $24.86 \pm 9.21$ & $28.14 \pm 4.67$ & $29.00 \pm 3.92$ & $28.86 \pm 4.60$ & $51.71 \pm 10.16$ \\
\hline \multicolumn{7}{|c|}{ - } \\
\hline $\mathrm{T} / \mathrm{T}$ & $31.05 \pm 8.10$ & $25.05 \pm 6.51$ & $28.46 \pm 5.32$ & $28.87 \pm 6.26$ & $24.95 \pm 6.46$ & $50.91 \pm 10.49$ \\
\hline $\mathrm{T} / \mathrm{C}$ & $31.47 \pm 7.51$ & $25.09 \pm 7.13$ & $28.26 \pm 6.34$ & $29.46 \pm 4.73$ & $26.53 \pm 5.91$ & $51.73 \pm 10.31$ \\
\hline $\mathrm{C} / \mathrm{C}$ & $29.71 \pm 9.62$ & $25.43 \pm 7.23$ & $30.71 \pm 4.61$ & $32.43 \pm 7.53$ & $24.14 \pm 8.61$ & $49.57 \pm 11.43$ \\
\hline Main effect of the genotype & 0.706 & 0.845 & 0.202 & 0.500 & 0.688 & 0.928 \\
\hline $\begin{array}{l}\text { Interaction between the } \\
\text { genotype and sex }\end{array}$ & 0.963 & 0.864 & 0.765 & 0.566 & 0.034 & 0.687 \\
\hline \multicolumn{7}{|l|}{ rs 1805502} \\
\hline \multicolumn{7}{|l|}{ Genotype (male) } \\
\hline $\mathrm{T} / \mathrm{T}$ & $28.90 \pm 7.97$ & $24.52 \pm 6.59$ & $26.17 \pm 5.92$ & $28.72 \pm 6.93$ & $26.83 \pm 6.64$ & $52.27 \pm 9.41$ \\
\hline $\mathrm{T} / \mathrm{C}$ & $29.96 \pm 7.91$ & $23.42 \pm 7.04$ & $24.63 \pm 7.20$ & $28.08 \pm 5.65$ & $23.83 \pm 7.39$ & $50.52 \pm 10.24$ \\
\hline $\mathrm{C} / \mathrm{C}$ & $28.29 \pm 7.41$ & $24.86 \pm 9.21$ & $28.14 \pm 4.67$ & $29.00 \pm 3.92$ & $28.86 \pm 4.60$ & $51.71 \pm 10.16$ \\
\hline \multicolumn{7}{|l|}{ Genotype (female) } \\
\hline $\mathrm{T} / \mathrm{T}$ & $31.06 \pm 8.06$ & $25.20 \pm 6.68$ & $28.56 \pm 5.40$ & $28.92 \pm 6.25$ & $25.02 \pm 6.47$ & $50.77 \pm 10.53$ \\
\hline $\mathrm{T} / \mathrm{C}$ & $31.46 \pm 7.57$ & $24.84 \pm 6.88$ & $28.10 \pm 6.25$ & $29.39 \pm 4.73$ & $26.45 \pm 5.91$ & $51.96 \pm 10.21$ \\
\hline $\mathrm{C} / \mathrm{C}$ & $29.71 \pm 9.62$ & $25.43 \pm 7.23$ & $30.71 \pm 4.61$ & $32.43 \pm 7.53$ & $24.14 \pm 8.61$ & $49.57 \pm 11.43$ \\
\hline Main effect of the genotype & 0.709 & 0.757 & 0.175 & 0.498 & 0.655 & 0.951 \\
\hline $\begin{array}{l}\text { Interaction between the } \\
\text { genotype and sex }\end{array}$ & 0.962 & 0.938 & 0.837 & 0.588 & 0.040 & 0.623 \\
\hline
\end{tabular}

Abbreviations: GRIN2B = N-methyl-D-aspartate receptor subunit $2 B$ gene; $N E O-F F I=$ Neuroticism Extraversion Openness-Five Factor Inventory; SNP = single nucleotide polymorphism; STAI = State-Trait Anxiety Inventory. 
Table 2. Effect of GRIN2B haplotypes on NEO-FFI and STAI dimension scores.

\begin{tabular}{|c|c|c|c|c|c|}
\hline \multirow[t]{2}{*}{ Dimension } & \multicolumn{3}{|c|}{ Haplotype } & \multirow{2}{*}{$\begin{array}{l}\text { Beta (regression } \\
\text { coefficient) }\end{array}$} & \multirow[t]{2}{*}{ p Value } \\
\hline & rs1806201 & rs1805247 & rs1805502 & & \\
\hline \multicolumn{6}{|l|}{ NEO-FFI } \\
\hline \multicolumn{6}{|l|}{ Neuroticism } \\
\hline Total & $\mathrm{T}$ & $\mathrm{T}$ & $\mathrm{T}$ & 0.244 & 0.723 \\
\hline Total & $\mathrm{C}$ & $\mathrm{C}$ & $\mathrm{C}$ & -0.127 & 0.880 \\
\hline Total & $\mathrm{C}$ & $\mathrm{T}$ & $\mathrm{T}$ & -0.190 & 0.794 \\
\hline Male & $\mathrm{T}$ & $\mathrm{T}$ & $\mathrm{T}$ & -0.313 & 0.827 \\
\hline Male & $\mathrm{C}$ & $\mathrm{C}$ & $\mathrm{C}$ & 0.125 & 0.933 \\
\hline Male & $\mathrm{C}$ & $\mathrm{T}$ & $\mathrm{T}$ & 0.194 & 0.891 \\
\hline Female & $\mathrm{T}$ & $\mathrm{T}$ & $\mathrm{T}$ & 0.308 & 0.696 \\
\hline Female & $\mathrm{C}$ & $\mathrm{C}$ & $\mathrm{C}$ & 0.015 & 0.988 \\
\hline Female & $\mathrm{C}$ & $\mathrm{T}$ & $\mathrm{T}$ & -0.381 & 0.655 \\
\hline \multicolumn{6}{|c|}{ Extraversion } \\
\hline Total & $\mathrm{T}$ & $\mathrm{T}$ & $\mathrm{T}$ & 0.921 & 0.119 \\
\hline Total & $\mathrm{C}$ & $\mathrm{C}$ & $\mathrm{C}$ & -0.288 & 0.690 \\
\hline Total & $\mathrm{C}$ & $\mathrm{T}$ & $\mathrm{T}$ & -0.966 & 0.124 \\
\hline Male & $\mathrm{T}$ & $\mathrm{T}$ & $\mathrm{T}$ & -0.126 & 0.922 \\
\hline Male & $\mathrm{C}$ & $\mathrm{C}$ & $\mathrm{C}$ & -0.230 & 0.864 \\
\hline Male & $\mathrm{C}$ & $\mathrm{T}$ & $\mathrm{T}$ & 0.332 & 0.794 \\
\hline Female & $\mathrm{T}$ & $\mathrm{T}$ & $\mathrm{T}$ & 1.186 & 0.076 \\
\hline Female & $\mathrm{C}$ & $\mathrm{C}$ & $\mathrm{C}$ & -0.190 & 0.829 \\
\hline \multirow{2}{*}{\multicolumn{6}{|c|}{ Openness }} \\
\hline & & & & & \\
\hline Total & $\mathrm{T}$ & $\mathrm{T}$ & $\mathrm{T}$ & 0.193 & 0.711 \\
\hline Total & $\mathrm{C}$ & $\mathrm{C}$ & $\mathrm{C}$ & -0.120 & 0.850 \\
\hline Total & $\mathrm{C}$ & $\mathrm{T}$ & $\mathrm{T}$ & -0.221 & 0.688 \\
\hline Male & $\mathrm{T}$ & $\mathrm{T}$ & $\mathrm{T}$ & -0.236 & 0.840 \\
\hline Male & $\mathrm{C}$ & $\mathrm{C}$ & $\mathrm{C}$ & 0.187 & 0.878 \\
\hline Male & $\mathrm{C}$ & $\mathrm{T}$ & $\mathrm{T}$ & 0.063 & 0.957 \\
\hline Female & $\mathrm{T}$ & $\mathrm{T}$ & $\mathrm{T}$ & 0.175 & 0.758 \\
\hline Female & $\mathrm{C}$ & $\mathrm{C}$ & $\mathrm{C}$ & 0.104 & 0.888 \\
\hline Female & $\mathrm{C}$ & $\mathrm{T}$ & $\mathrm{T}$ & -0.398 & 0.517 \\
\hline \multicolumn{6}{|c|}{ Agreeableness } \\
\hline Total & $\mathrm{T}$ & $\mathrm{T}$ & $\mathrm{T}$ & 0.014 & 0.978 \\
\hline Total & $\mathrm{C}$ & $\mathrm{C}$ & $\mathrm{C}$ & 0.529 & 0.395 \\
\hline Total & $\mathrm{C}$ & $\mathrm{T}$ & $\mathrm{T}$ & -0.458 & 0.397 \\
\hline Male & $\mathrm{T}$ & $\mathrm{T}$ & $\mathrm{T}$ & -0.033 & 0.977 \\
\hline Male & $\mathrm{C}$ & $\mathrm{C}$ & $\mathrm{C}$ & -0.107 & 0.927 \\
\hline Male & $\mathrm{C}$ & $\mathrm{T}$ & $\mathrm{T}$ & 0.129 & 0.907 \\
\hline Female & $\mathrm{T}$ & $\mathrm{T}$ & $\mathrm{T}$ & -0.012 & 0.984 \\
\hline Female & $\mathrm{C}$ & $\mathrm{C}$ & $\mathrm{C}$ & 0.941 & 0.210 \\
\hline \multirow{2}{*}{\multicolumn{6}{|c|}{ Conscientiousness }} \\
\hline & & & & & \\
\hline Total & $\mathrm{T}$ & $\mathrm{T}$ & $\mathrm{T}$ & -0.762 & 0.176 \\
\hline Total & $\mathrm{C}$ & $\mathrm{C}$ & $\mathrm{C}$ & 0.456 & 0.508 \\
\hline Total & $\mathrm{C}$ & $\mathrm{T}$ & $\mathrm{T}$ & 0.460 & 0.443 \\
\hline Male & $\mathrm{T}$ & $\mathrm{T}$ & $\mathrm{T}$ & -0.769 & 0.544 \\
\hline Male & $\mathrm{C}$ & $\mathrm{C}$ & $\mathrm{C}$ & -0.248 & 0.851 \\
\hline Male & $\mathrm{C}$ & $\mathrm{T}$ & $\mathrm{T}$ & 0.978 & 0.435 \\
\hline Female & $\mathrm{T}$ & $\mathrm{T}$ & $\mathrm{T}$ & -0.746 & 0.238 \\
\hline Female & $\mathrm{C}$ & $\mathrm{C}$ & $\mathrm{C}$ & 0.750 & 0.364 \\
\hline Female & $\mathrm{C}$ & $\mathrm{T}$ & $\mathrm{T}$ & 0.285 & 0.678 \\
\hline \multicolumn{6}{|l|}{ STAI } \\
\hline \multicolumn{6}{|c|}{ Trait anxiety } \\
\hline Total & $\mathrm{T}$ & $\mathrm{T}$ & $\mathrm{T}$ & -0.429 & 0.629 \\
\hline Total & $\mathrm{C}$ & $\mathrm{C}$ & $\mathrm{C}$ & 0.149 & 0.890 \\
\hline Total & $\mathrm{C}$ & $\mathrm{T}$ & $\mathrm{T}$ & 0.500 & 0.596 \\
\hline Male & $\mathrm{T}$ & $\mathrm{T}$ & $\mathrm{T}$ & 0.113 & 0.949 \\
\hline Male & $\mathrm{C}$ & $\mathrm{C}$ & $\mathrm{C}$ & -0.755 & 0.682 \\
\hline Male & $\mathrm{C}$ & $\mathrm{T}$ & $\mathrm{T}$ & 0.574 & 0.744 \\
\hline Female & $\mathrm{T}$ & $\mathrm{T}$ & $\mathrm{T}$ & -0.577 & 0.578 \\
\hline Female & $\mathrm{C}$ & $\mathrm{C}$ & $\mathrm{C}$ & 0.537 & 0.691 \\
\hline Female & $\mathrm{C}$ & $\mathrm{T}$ & $\mathrm{T}$ & 0.481 & 0.668 \\
\hline
\end{tabular}

Abbreviations: GRIN2B $=N$-methyl-D-aspartate receptor subunit $2 B$ gene; $N E O-F F I=$ Neuroticism Extraversion Openness-Five Factor Inventory; STAI = State-Trait Anxiety Inventory. 


\section{Discussion}

The genotype and allele frequencies of the analysed polymorphisms in the participants were not significantly different from those reported in healthy Japanese participants (rs7301328: genotype: $\mathrm{p}=0.145$, allele: $\mathrm{p}=0.075$; rs1806201: genotype: $\mathrm{p}=0.475$, allele: $\mathrm{p}=$ 0.396; rs 1805247: genotype: $p=0.637$, allele: $p=0.416$; rs 1805502: genotype: $p=0.700$, allele: $p=0.427){ }^{14}$

To the best of our knowledge, analysis using NEO-FFI and STAI dimension scores for assessing personality traits has not been reported. In a young Chinese Han population, the rs1806201 polymorphism was positively associated with shrewdness measured by the 16 Personality Factor Questionnaire, but the significance was lost after correction for multi-testing. ${ }^{3}$ Although the rs 1806201 polymorphism is a silent (synonymous) mutation, ${ }^{30}$ it contributes to the selective regulation of the response inhibition process at the behavioural and neurophysiological levels. ${ }^{31}$ The response inhibition process is stronger in the combined $\mathrm{CT} / \mathrm{TT}$ genotype group than in the CC genotype group; this suggests that the variant $\mathrm{T}$ allele is associated with increased glutamatergic transmission. ${ }^{31}$ The glutamatergic neurotransmission system is involved in the characterisation of human behaviour and personality traits. Glutamate concentration in the anterior cingulate cortex is associated with sensation seeking, harm avoidance, and anxiety. ${ }^{32-34}$ Glutamate concentration in the dorsolateral prefrontal cortex is linked to extraversion among human personality traits. ${ }^{35}$ Our study failed to find any association between functional rs 1806201 polymorphism and personality traits in terms of NEO-FFI and STAI dimension scores; this may have been caused by the methodological approach. According to the Temperament and Character Inventory model developed by Cloninger et al, ${ }^{36}$ the three heritable personality dimensions (novelty seeking, harm avoidance, and reward dependence) are thought to reflect the activity of dopaminergic, serotonergic, and norepinephrinergic neurons, respectively. ${ }^{37}$ Meanwhile, glutamate in the central nervous system is closely related to monoamine neurons as a co-transmitter, and the presence of a glutamate neurotransmitter pool in serotonin, dopamine, and norepinephrine neurons has been confirmed. ${ }^{38}$ Under this system, the function of NMDA receptors including the GluN2B has been shown to be influenced by monoamine neurotransmitters..$^{39-41}$ Thus, analysis of personality traits based on the Cloninger theory may be able to detect a significant association with GRIN2B polymorphisms. In fact, glutamatergic-related genes such as the excitatory amino acid transporter 2 (EAAT2) and ionotropic glutamate receptor kainate 3 (GRIK3) polymorphisms are associated with several personality dimensions/subdimensions such as reward dependence and harm avoidance, as measured by Temperament and Character Inventory. ${ }^{42,43}$

In our study, $\mathrm{LD}$ analysis identified a nearly complete LD between the rs1805247 and rs1805502 polymorphisms, and a haplotype block based on the rs1806201, rs1805247, and rs1805502 polymorphisms. The G allele of the rs1805247 polymorphism induces greater synaptic facilitation and greater long-term potentiation-like synaptic plasticity after intermittent theta-burst stimulation, and it has been suggested that individuals carrying this allele have enhanced glutamate NMDA receptor function. ${ }^{44}$ The exact effect of the rs 1805502 polymorphism on the expression or function of GRIN2B is unknown ${ }^{45}$ but the polymorphism is located in the same LD block as rs1806201 and rs1805247, which might affect glutamatergic pathways and gene expression. Furthermore, as an extension of this, a haplotype composed of some SNPs could be a meaningful mediator for elucidating genes involved in the characterisation of personality traits..$^{46,47}$ The effects of a haplotype CTT (rs1806201-rs1805247-rs1805502) on extraversion in female participants was lost after correction for multiple testing. Thus, it is necessary to increase the number of male participants to improve the statistical power of the analysis of the effect by sex.

This study has several limitations. The number of participants needed was calculated using $\mathrm{G}^{*}$ Power version 3.1.9.2 (http://www.gpower.hhu.de/). ${ }^{48}$ The effect size in the two-way analysis of variance was set to 0.25 (medium effect), and the power was $0.8(\alpha=0.05){ }^{49}$ Consequently, when analysing the interaction between genotypes and sex for the NEO-FFI or STAI dimension scores, the required total number of participants was 158 (158 / (3 [genotypes] $\times 2$ [sexes] $)=$ approximately 27 participants per cell). For instance, the number of male participants with the $\mathrm{C} / \mathrm{C}$ genotype of the rs1805247 and rs1805502 polymorphisms was 8 . A significant association could not be detected probably because of low statistical power. Although all participants were supposedly healthy young people, their mental health was not confirmed by a psychiatrist. Therefore, we are unable to completely eliminate a confounding factor for the presence or absence of a mental disorder in participants.

\section{Conclusion}

There was no significant association between selected GRIN2B polymorphisms and personality traits in a young Japanese population, based on NEO-FFI and STAI dimension scores. Further large-scale studies involving more participants and using a full version of the Revised NEO Personality Inventory and Temperament and Character Inventory are needed to clarify the relationship between GRIN2B polymorphisms and personality traits.

\section{Acknowledgement}

This research was supported by a research project grant awarded by the Azabu University.

\section{Declaration}

The authors have no conflicts of interest to disclose. 


\section{References}

1. Bouchard TJ Jr. Genes, environment, and personality. Science 1994;264:1700-1. cross re

2. Ebstein RP, Benjamin J, Belmaker RH. Personality and polymorphisms of genes involved in aminergic neurotransmission. Eur J Pharmacol 2000;410:205-14. cross re

3. Gong P, Zheng A, Zhang K, Lei X, Li F, Chen D, et al. Association analysis between 12 genetic variants of ten genes and personality traits in a young Chinese Han population. J Mol Neurosci 2010;42:1206. Eross re

4. Metzler M. Mutations in NMDA receptors influence neurodevelopmental disorders causing epilepsy and intellectual disability. Clin Genet 2011;79:219-20. Eross re

5. Pérez-Otaño I, Larsen RS, Wesseling JF. Emerging roles of GluN3containing NMDA receptors in the CNS. Nat Rev Neurosci 2016;17:623-35. Eross ret

6. Laube B, Hirai H, Sturgess M, Betz H, Kuhse J. Molecular determinants of agonist discrimination by NMDA receptor subunits: analysis of the glutamate binding site on the NR2B subunit. Neuron 1997;18:493503. Eross re

7. Wyllie DJ, Livesey MR, Hardingham GE. Influence of GluN2 subunit identity on NMDA receptor function. Neuropharmacology 2013;74:417. Eross ret

8. Monaco SA, Gulchina Y, Gao WJ. NR2B subunit in the prefrontal cortex: a double-edged sword for working memory function and psychiatric disorders. Neurosci Biobehav Rev 2015;56:127-38. Eross re

9. Lehner M, Wislowska-Stanek A, Skorzewska A, Maciejak P, Szyndler J, Turzynska D, et al. Expression of N-methyl-D-aspartate (R) (GluN2B) - subunits in the brain structures of rats selected for low and high anxiety. J Physiol Pharmacol 2011;62:473-82.

10. Feyissa AM, Chandran A, Stockmeier CA, Karolewicz B. Reduced levels of NR2A and NR2B subunits of NMDA receptor and PSD-95 in the prefrontal cortex in major depression. Prog Neuropsychopharmacol Biol Psychiatry 2009;33:70-5. Eross re

11. Preskorn SH, Baker B, Kolluri S, Menniti FS, Krams M, Landen JW. An innovative design to establish proof of concept of the antidepressant effects of the NR2B subunit selective N-methyl-Daspartate antagonist, CP-101,606, in patients with treatment-refractory major depressive disorder. J Clin Psychopharmacol 2008;28:6317. Eross re

12. Ibrahim L, Diaz Granados N, Jolkovsky L, Brutsche N, Luckenbaugh DA, Herring WJ, et al. A randomized, placebo-controlled, crossover pilot trial of the oral selective NR2B antagonist MK-0657 in patients with treatment-resistant major depressive disorder. J Clin Psychopharmacol 2012;32:551-7. Eross re

13. Mandich P, Schito AM, Bellone E, Antonacci R, Finelli P, Rocchi $\mathrm{M}$, et al. Mapping of the human NMDAR2B receptor subunit gene (GRIN2B) to chromosome 12p12. Genomics 1994;22:216-8. eross re

14. Ohtsuki T, Sakurai K, Dou H, Toru M, Yamakawa-Kobayashi K, Arinami T. Mutation analysis of the NMDAR2B (GRIN2B) gene in schizophrenia. Mol Psychiatry 2001;6:211-6. eross re

15. Fallin MD, Lasseter VK, Avramopoulos D, Nicodemus KK, Wolyniec PS, McGrath JA, et al. Bipolar I disorder and schizophrenia: a 440 -single-nucleotide polymorphism screen of 64 candidate genes among Ashkenazi Jewish case-parent trios. Am J Hum Genet 2005;77:918-36. Eross re

16. Avramopoulos D, Lasseter VK, Fallin MD, Wolyniec PS, McGrath JA, Nestadt G, et al. Stage II follow-up on a linkage scan for bipolar disorder in the Ashkenazim provides suggestive evidence for chromosome 12p and the GRIN2B gene. Genet Med 2007;9:74551. Eross ret

17. Martucci L, Wong AH, De Luca V, Likhodi O, Wong GW, King N, et al. N-methyl-D-aspartate receptor NR2B subunit gene GRIN2B in schizophrenia and bipolar disorder: polymorphisms and mRNA levels. Schizophr Res 2006;84:214-21. Eross re

18. Zhao Q, Che R, Zhang Z, Wang P, Li J, Li Y, et al. Positive association between GRIN2B gene and bipolar disorder in the Chinese Han population. Psychiatry Res 2011;185:290-2. cross re

19. Zhang C, Li Z, Wu Z, Chen J, Wang Z, Peng D, et al. A study of Nmethyl-D-aspartate receptor gene (GRIN2B) variants as predictors of treatment-resistant major depression. Psychopharmacology (Berl) 2014;231:685-93. Eross re

20. Wernicke C, Samochowiec J, Schmidt LG, Winterer G, Smolka M, Kucharska-Mazur J, et al. Polymorphisms in the N-methyl-D-aspartate receptor 1 and $2 \mathrm{~B}$ subunits are associated with alcoholism-related traits. Biol Psychiatry 2003;54:922-8. cross ret

21. Ness V, Arning L, Niesert HE, Stüttgen MC, Epplen JT, Beste C. Variations in the GRIN2B gene are associated with risky decisionmaking. Neuropharmacology 2011;61:950-6. cross re

22. Lee LC, Cho YC, Lin PJ, Yeh TC, Chang CY, Yeh TK. Influence of genetic variants of the N-Methyl-D-Aspartate Receptor on emotion and social behavior in adolescents. Neural Plast 2016;2016:6851592. Eross re

23. Shimonaka Y, Nakazato K, Gondo Y, Takayama M. NEO-PI-R and NEO-FFI Manual for the Japanese Version. Tokyo: Tokyo Shinri; 1999.

24. Nakazato K, Mizuguchi T. Development and validation of Japanese version of State-Trait Anxiety Inventory: a study with female subjects. Jpn J Psychosom Med 1982;22:107-12.

25. Mellott KG, Sharp PB, Anderson LM. Biobehavioral measures in a critical-care healing environment. J Holist Nurs 2008;26:128-35. cross re

26. Yoshimura K, Nakamura K, Ono Y, Sakurai A, Saito N, Mitani M, et al. Reliability and validity of a Japanese version of the NEO Five Factor Inventory (NEO-FFI): a population-based survey in Aomori prefecture. Jpn J Stress Sci 1998;13:45-53.

27. Tsai SJ, Liu HC, Liu TY, Cheng CY, Hong CJ. Association analysis for the genetic variants of the NMDA receptor subunit $2 \mathrm{~b}$ and Alzheimer's disease. Dement Geriatr Cogn Disord 2002;13:91-4. cross ret

28. Barrett JC, Fry B, Maller J, Daly MJ. Haploview: analysis and visualization of $L D$ and haplotype maps. Bioinformatics 2005;21:2635. eross ret

29. Purcell S, Neale B, Todd-Brown K, Thomas L, Ferreira MA, Bender D, et al. PLINK: a tool set for whole-genome association and populationbased linkage analyses. Am J Hum Genet 2007;81:559-75. Eross ret

30. Nishiguchi N, Shirakawa O, Ono H, Hashimoto T, Maeda K. Novel polymorphism in the gene region encoding the carboxyl-terminal intracellular domain of the NMDA receptor $2 \mathrm{~B}$ subunit: analysis of association with schizophrenia. Am J Psychiatry 2000;157:132931. cross re

31. Beste C, Baune BT, Domschke K, Falkenstein M, Konrad C. Dissociable influences of NR2B-receptor related neural transmission on functions of distinct associative basal ganglia circuits. Neuroimage 2010;52:309-15. Eross re

32. Gallinat J, Kunz D, Lang UE, Neu P, Kassim N, Kienast T, et al. Association between cerebral glutamate and human behaviour: the sensation seeking personality trait. Neuroimage 2007;34:671-8. Eross re

33. Kim HJ, Kim JE, Cho G, Song IC, Bae S, Hong SJ, et al. Associations between anterior cingulate cortex glutamate and gamma-aminobutyric acid concentrations and the harm avoidance temperament. Neurosci Lett 2009;464:103-7. Eross ret

34. Modi S, Rana P, Kaur P, Rani N, Khushu S. Glutamate level in anterior cingulate predicts anxiety in healthy humans: a magnetic resonance spectroscopy study. Psychiatry Res 2014;224:34-41. Eross re

35. Grimm S, Schubert F, Jaedke M, Gallinat J, Bajbouj M. Prefrontal cortex glutamate and extraversion. Soc Cogn Affect Neurosci 2012;7:811-8. cross re

36. Cloninger CR, Svrakic DM, Przybeck TR. A psychobiological model of temperament and character. Arch Gen Psychiatry 1993;50:97590. cross re

37. Cloninger CR. A systematic method for clinical description and classification of personality variants. A proposal. Arch Gen Psychiatry 1987;44:573-88. Eross re

38. Trudeau LE. Glutamate co-transmission as an emerging concept in monoamine neuron function. J Psychiatry Neurosci 2004;29:296-310.

39. Masuko T, Suzuki I, Kizawa Y, Kusama-Eguchi K, Watanabe K, Kashiwagi K, et al. Monoamines directly inhibit N-methyl-D-aspartate 
receptors expressed in Xenopus oocytes in a voltage-dependent manner. Neurosci Lett 2004;371:30-3. Eross re

40. Yuen EY, Jiang Q, Chen P, Gu Z, Feng J, Yan Z. Serotonin 5-HT1A receptors regulate NMDA receptor channels through a microtubuledependent mechanism. J Neurosci 2005;25:5488-501. cross ref

41. Bortolato M, Godar SC, Melis M, Soggiu A, Roncada P, Casu A, et al. NMDARs mediate the role of monoamine oxidase A in pathological aggression. J Neurosci 2012;32:8574-82. Eross re

42. Matsumoto Y, Suzuki A, Ishii G, Oshino S, Otani K, Goto K. The -181 $\mathrm{A} / \mathrm{C}$ polymorphism in the excitatory amino acid transporter- 2 gene promoter affects the personality trait of reward dependence in healthy subjects. Neurosci Lett 2007;427:99-102. cross re

43. Minelli A, Scassellati C, Bonvicini C, Perez J, Gennarelli M. An association of GRIK3 Ser310Ala functional polymorphism with personality traits. Neuropsychobiology 2009;59:28-33. eross re

44. Mori F, Ribolsi M, Kusayanagi H, Siracusano A, Mantovani V, Marasco E, et al. Genetic variants of the NMDA receptor influence cortical excitability and plasticity in humans. J Neurophysiol 2011;106:163743. Eross re

45. Che F, Zhang Y, Wang G, Heng X, Liu S, Du Y. The role of GRIN2B in Tourette syndrome: results from a transmission disequilibrium study. $\mathrm{J}$ Affect Disord 2015;187:62-5. Eross ret

46. Dlugos AM, Palmer AA, de Wit H. Negative emotionality: monoamine oxidase B gene variants modulate personality traits in healthy humans. J Neural Transm (Vienna) 2009;116:1323-34. Eross re

47. Kazantseva A, Gaysina D, Malykh S, Khusnutdinova E. The role of dopamine transporter (SLC6A3) and dopamine D2 receptor/ankyrin repeat and kinase domain containing 1 (DRD2/ANKK1) gene polymorphisms in personality traits. Prog Neuropsychopharmacol Biol Psychiatry 2011;35:1033-40. cross re

48. Faul F, Erdfelder E, Lang AG, Buchner A. G*Power 3: a flexible statistical power analysis program for the social, behavioral, and biomedical sciences. Behav Res Methods 2007;39:175-91. cross re

49. Cohen J. A power primer. Psychol Bull 1992;112:155-9. Eross re 